\title{
Gene Expression and Hormone Secretion Profile of Urotensin I Associated with Osmotic Challenge in Caudal Neurosecretory System of the Euryhaline Flounder, Platichthys flesus
}

Dol:

10.1016/j.ygcen.2019.01.004

Document Version

Accepted author manuscript

Link to publication record in Manchester Research Explorer

Citation for published version (APA):

Lu, W., Zhu, G., Chen, A., Li, X., Mccrohan, C. R., \& Balment, R. (2019). Gene Expression and Hormone Secretion Profile of Urotensin I Associated with Osmotic Challenge in Caudal Neurosecretory System of the Euryhaline Flounder, Platichthys flesus. General and comparative endocrinology. https://doi.org/10.1016/j.ygcen.2019.01.004

\section{Published in:}

General and comparative endocrinology

\section{Citing this paper}

Please note that where the full-text provided on Manchester Research Explorer is the Author Accepted Manuscript or Proof version this may differ from the final Published version. If citing, it is advised that you check and use the publisher's definitive version.

\section{General rights}

Copyright and moral rights for the publications made accessible in the Research Explorer are retained by the authors and/or other copyright owners and it is a condition of accessing publications that users recognise and abide by the legal requirements associated with these rights.

\section{Takedown policy}

If you believe that this document breaches copyright please refer to the University of Manchester's Takedown Procedures [http://man.ac.uk/04Y6Bo] or contact uml.scholarlycommunications@manchester.ac.uk providing relevant details, so we can investigate your claim.

\section{OPEN ACCESS}




\section{Accepted Manuscript}

Gene Expression and Hormone Secretion Profile of Urotensin I Associated with GENERAL AND COMPARATIVE ENDOCRINOLOGY

Osmotic Challenge in Caudal Neurosecretory System of the Euryhaline Flounder, Platichthys flesus

Weiqun Lu, Gege Zhu, Aqin Chen, Xiaoxue Li, Catherine R. McCrohan, Richard Balment

PII: S0016-6480(18)30380-0

DOI: https://doi.org/10.1016/j.ygcen.2019.01.004

Reference: YGCEN 13098

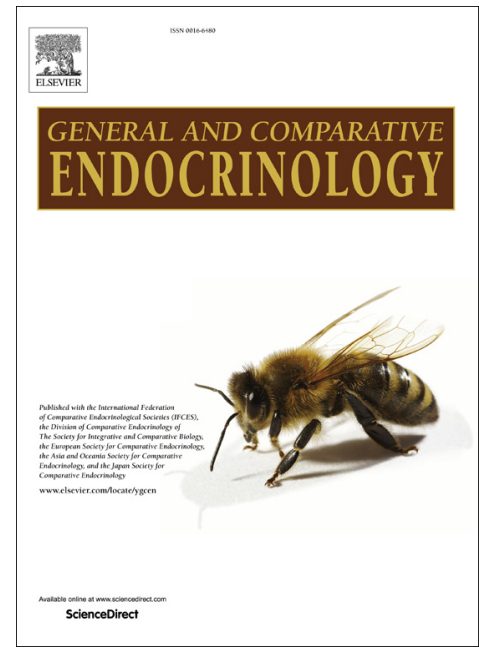

To appear in:

General and Comparative Endocrinology

Received Date: $\quad 9$ July 2018

Revised Date: $\quad 3$ January 2019

Accepted Date: $\quad 8$ January 2019

Please cite this article as: Lu, W., Zhu, G., Chen, A., Li, X., McCrohan, C.R., Balment, R., Gene Expression and Hormone Secretion Profile of Urotensin I Associated with Osmotic Challenge in Caudal Neurosecretory System of the Euryhaline Flounder, Platichthys flesus, General and Comparative Endocrinology (2019), doi: https://doi.org/ 10.1016/j.ygcen.2019.01.004

This is a PDF file of an unedited manuscript that has been accepted for publication. As a service to our customers we are providing this early version of the manuscript. The manuscript will undergo copyediting, typesetting, and review of the resulting proof before it is published in its final form. Please note that during the production process errors may be discovered which could affect the content, and all legal disclaimers that apply to the journal pertain. 
Gene Expression and Hormone Secretion Profile of Urotensin I Associated with Osmotic

Challenge in Caudal Neurosecretory System of the Euryhaline Flounder, Platichthys flesus

Weiqun $\mathrm{Lu}^{1,2,3 *^{+}}$, Gege $\mathrm{Zhu}^{1,2,3+}$, Aqin Chen ${ }^{1,2,3+}$, Xiaoxue $\mathrm{Li}^{1,2,3}$, Catherine R. McCrohan ${ }^{4}$ and Richard Balment ${ }^{4}$

${ }^{1}$ National Demonstration Center for Experimental Fisheries Science Education, Shanghai Ocean University, Shanghai, 201306, China

${ }^{2}$ Key Laboratory of Exploration and Utilization of Aquatic Genetic Resources, Ministry of Education, Shanghai 201306, China

3 International Research Center for Marine Biosciences at Shanghai Ocean University, Ministry of Science and Technology, China

4 Faculty of Biology, Medicine and Health, The University of Manchester, Oxford Road, M13 9PT, UK

${ }^{+}$Joint first authors

*Corresponding author:wqlv@shou.edu.cn 
Abstract: The caudal neurosecretory system (CNSS) is a part of stress response system, a neuroendocrine structure unique to fish. To gain a better understanding of the physiological roles of CNSS in fluid homeostasis, we characterized the tissue distribution of Urotensin I (UI) expression in European flounder (Platichthys flesus), analyzed the effect chronic exposure to seawater (SW) or freshwater $(\mathrm{FW})$, transfer from $\mathrm{SW}$ to $\mathrm{FW}$, and reverse transfer on mRNA levels of UI, L-type $\mathrm{Ca}^{2+}$ channels and Ca-activated $\mathrm{K}^{+}$channels transcripts in CNSS. The tissue distribution demonstrated that the CNSS is dominant sites of UI expression, and UI mRNA level in fore brain appeared greater than other non-CNSS tissues. There were no consistent differences in CNSS UI expression or urophysis UI content between SW- and FWadapted fish in July and September. After transfer from SW to FW, at $8 \mathrm{~h}$ CNSS UI expression was significantly increased, but urophysis UI content was no significantly changes. At $24 \mathrm{~h}$ transfer from SW to FW, expression of CNSS UI was no apparent change and urophsyis UI content was reduced. At $8 \mathrm{~h}$ and $24 \mathrm{~h}$ after transfer from FW to SW UI expression and urophysis UI content was no significantly effect. The expression of bursting dependent L-type $\mathrm{Ca}^{2+}$ channels and Ca-activated $\mathrm{K}^{+}$channels in $\mathrm{SW}$-adapted fish significantly decreased compared to those in FW-adapted. However, there were no differences in transfer from SW to $\mathrm{FW}$ or from $\mathrm{FW}$ to $\mathrm{SW}$ at $8 \mathrm{~h}$ and $24 \mathrm{~h}$. Thus, these results suggest CNSS UI acts as a modulator in response to osmotic stress and plays important roles in the body fluid homeostasis.

Keywords: Urotensin I; Flounder; Caudal neurosecretory system; Osmoregulation 


\section{Introduction}

Urotensin I (UI) is a 41-amino acid neuroendocrine peptide that belongs to the superfamily of corticotropin-releasing factors, isolated first from the urophysis of white sucker Catostomus commersoni (Lederis et al., 1982). In mammals, the UI orthologue urocotrins regulate the stress response and many other vital functions such as regulation of glucocorticoid synthesis (Bernier et al., 1999), cardiovascular homeostasis (Conlon et al., 1996) and inhibition of appetite central nervous system functions (Yasuda et al., 2012), whereas in fish an involvement for UI in osmoregulation has also been suggested (Craig et al., 2005). However, many fundamental questions regarding the physiological roles of the UI in the modulation of osmotic stress remain unanswered (McCrohan et al., 2007).

The UI peptide has been isolated and characterized in several teleosts, mammals and the frog (Lederis et al., 1982; Lu et al., 2004). In euryhaline flounder (Platichthys flesus), UI is predominantly expressed and synthesed in the caudal neurosecretory system (CNSS), contributing most circulating UI (Lu et al., 2004). The CNSS of P. flesus has suggested roles in osmoregulatory, reproductive and nutritional adaptation, as fish migrate between seawater (winter) and brackish/freshwater (summer) environments (Flik et al., 2006). This neuroendocrine structure unique to fish, which comprised magnocellular neurosecretory Dahlgren cells, project to a discrete neurohaemal organ, urophysis. A number of neuron-peptides such as UI and corticotropin releasing hormone (CRH) (Lu et al., 2004), urotenisn II (UII) (Lu et al., 2006), Stanniocalcin (STC) (Greenwood et al., 2009)and parathyroid hormone-related protein (PTHrP) (Lu et al., 2017)are potentially secreted from the urophysis directly into the caudal vein and renal-portal system, ensuring their rapid 
delivery to possible peripheral target organs - kidney, intestine, gonad, spleen and liver.

As neuroendocrine cells, the secretory output of the Dahlgren cells depends as much on their electrical activity (i.e., firing frequency) which depends, in turn, on excitatory and inhibitory inputs as their expression of neuropeptides and ion channels. Our previous study has identified that the firing pattern is dependent on intrinsic membrane properties, a long-duration (up to 200s) burst depends on a post-stimulus after depolarising potential (ADP) in depolarised cells (Brierley et al., 2004). Our studies suggest that ADP is due to an L-type $\mathrm{Ca}^{2+}$ conductance. Firing activity within a burst is maintained by short-duration $(<100 \mathrm{~ms})$ depolarising after potentials (DAP), which follow each spike and are again voltage- and L-type $\mathrm{Ca}^{2+}$ channel-dependent (Brierley et al., 2001; Brierley et al., 2004). Our findings suggest that voltage-dependent bursting activity in Dahlgren cells is dependent on L-type $\mathrm{Ca}^{2+}$ conductance, with some role for $\mathrm{Ca}^{2+}$-activated $\mathrm{K}^{+}$conductance in burst termination. Modulators that influence these conductances, or resting membrane potential, could have profound effects on firing pattern and promote more efficient peptide release.

In rainbow trout, studies indicate that CNSS UI neurons responded to the stress is stressor-, time-, and region-specific (Bernier et al., 2008). Physical restraint, subordination, and hypoxia elicited no marked changes of UI mRNA expression in neurons (Bernier et al., 2008; Lu et al., 2004). However, osmolality and hyperammonemia stressor are associated with increase in UI gene expression (Bernier et al., 2008; Craig et al., 2005). Isolation caused a decrease in the expression of UI transcripts (Bernier et al., 2008). These results suggest that the regulation of UI expression in teleosts maybe stressor-specific and species-specific, and the potential physiological roles of UI in different fish species are still a matter of discussion. 
Thus, in order to assess the potential roles played by CNSS in the acclimation to low salinity stress in euryhaline flounder (P. flesus), we first characterized the mRNA levels of UI in different tissues by real-time PCR to assess the relative importance of the CNSS as sites of UI expression in this species, and investigated the impacts of hyposmosis on the CNSS UI,

L-type $\mathrm{Ca}^{2+}$ channels and Ca-activated $\mathrm{K}^{+}$channels mRNA levels and the urophysis UI content.

\section{Materials and methods}

\subsection{Animals}

The flounder (Platichthys flesus, 360-500g) were collected from Morecambe Bay (Cumbria, UK) and transported to aquarium facilities at the University of Manchester. They were then maintained in re-circulating, filtered $100 \% \mathrm{SW}$ at $10-12{ }^{\circ} \mathrm{C}$ under $12 \mathrm{~h}: 12 \mathrm{~h}$ light: dark photoperiod, for at least 2 weeks prior to experimentation. Fish were not fed during this time. All experiments were performed in accordance with United Kingdom Home Office Regulatory requirements and local Ethics Committee approval.

\subsection{Experimental protocol}

The salinity challenge experiment was performed as previous described by $\mathrm{Lu}$ et al (Lu et al., 2006). In brief, fish were held for at least 2 weeks in either medium prior to sampling. In order to examine the effect of osmotic challenge and control for the handling and disturbance of fish, SW-adapted fish were removed from 100\% SW tanks and transferred directly to equivalent FW tanks (experimental transfer) or new 100\% SW tanks (time-matched control). This experiment was carried out in July. A second group of fish were fully adapted to 
FW (at least 2 weeks) and then removed from 100\% FW tanks and transferred directly to equivalent SW tanks (experimental transfer) or new 100\% FW tanks (time-matched control). This experiment was carried out in September. Groups of 8 fish were sampled 8 and $24 \mathrm{~h}$ after transfer. Blood samples $(3-5 \mathrm{ml})$ were taken within $90 \mathrm{~s}$ by direct needle puncture of caudal blood vessels. Fish were humanely killed using Schedule One procedure detailed under UK Home Office licence procedures, and tissues were removed and snap frozen in liquid nitrogen. All samples were taken during the daytime.

\subsection{RNA preparation}

Different tissues were dissected out from $20 \mathrm{SW}$-adapted fish. These included the CNSS (the caudal 8 segments of the spinal cord) and separate urophysis. Brain tissue was further separated into 5 regions (forebrain, midbrain, hindbrain, hypothalamus and pituitary). Tissues were homogenized in $4 \mathrm{M}$ guanidium thiocyanate buffer $(\mathrm{pH} \quad 7.5)$ containing $1 \%$ $\beta$-mercaptoethanol. Total RNA was extracted by ultracentrifugation at $27,000 \mathrm{~g}$ for $20 \mathrm{~h}$ on a bed of 5.7 M CsTFA (Amersham-Phamacia Biotech, UK). RNA for distribution RT-PCR was treated with DNase (Roche, UK).

For chronically SW or FW adapted groups and SW or FW transfer experiment samples, total RNA was extracted from individual fish CNSS by Trizol ${ }^{\mathrm{TM}}$ (Invitrogen, UK).

\subsection{Plasma osmolality and ion measurements}

Plasma osmolality was measured by freezing point depression (Roebing Osmometer, Berlin, Germany), sodium concentration were determined by flame photometry (Corning 480, Corning Ltd, Essex, UK) and chloride concentrations were analyzed by electrometric titration (Chloride Analyser 925, Corning Ltd., Essex, UK). 


\subsection{Hormone measurements}

UI content of isolated urophysis were determined in triplicate by RIA ( $\mathrm{Lu}$ et al., 2013), using anti-serum which was raised in rabbit against the last 18 amino acid residues at the $\mathrm{C}$ terminus of flounder UI by BioCarta, UK. The affinity purified antibody was used at a final dilution of 1:600. The iodination of flounder 0Tyr-UI peptide was performed using the Iodogen method. The ${ }^{0}$ Tyr-UI- ${ }^{125}$ I was then purified by reverse-phase high performance liquid chromatography (HPLC, Vista 5500, Varian UK) using C5-column (Phenomenex, UK). The large single peak eluted after 42 min, corresponding with an acetonitrile concentration of $42 \%$, was found to be ${ }^{0} \mathrm{Tyr}-\mathrm{UI}-{ }^{125} \mathrm{I}$, and this was confirmed following successful binding (typically $81 \%$ ) with an excess of the UI antibody (final dilution 1/50). Radioimmunoassay for ${ }^{0}$ Tyr-UI- ${ }^{125}$ I, antibody, and standards (synthetic full length UI peptide from BioCarta, UK) were all prepared in assay buffer to final dilutions of $2500 \mathrm{cpm} / \mathrm{tube}, 1: 600$, and $5.29 \times 10^{-8}-1.03 \times 10^{-10} \mathrm{~mol} / \mathrm{L} \mathrm{M} \mathrm{UI} /$ tube, respectively. Intra- and inter-assay coefficients of variation were $6.1 \%$ and $12.3 \%$ ( $\mathrm{n}=10$ for both). There was no displacement of UI radiolabel with any of flounder CRH, UII, PTHrP and AVT peptides tested in standard concentration range indicating that there was no cross reactivity with the antibody and the specificity of the assay for UI. The UI RIA has an approximate working range of $1 \times 10^{-8}-1 \times 10^{-10} \mathrm{~mol} / \mathrm{L}$.

Each snap frozen urophysis was homogenised in $1 \mathrm{ml}$ of ice cold $0.01 \mathrm{M} \mathrm{HCl}$ for $10 \mathrm{~min}$ and then centrifuged for $10 \mathrm{~min}$ at $4^{\circ} \mathrm{C}$ and $3000 \mathrm{~g}$. The supernatant was frozen in liquid nitrogen, and stored at $-80^{\circ} \mathrm{C}$ until use in the RIA. This homogenate was used for the subsequent UI RIA's. The urophysial extract was diluted in assay buffer to 1 in 1000 for UI.

\subsection{Relative quantitative RT-PCR}


The quantitative real-time PCR reaction was carried out in 96-well qPCR plates on an ABI PRISM 7000 detector (Applied Biosystems, Foster City, CA). UI, L-type Ca2 ${ }^{+}$channel, Ca-activated $\mathrm{K}^{+}$channel and beta-actin primers were previously described by $\mathrm{Lu}$ et al. (Lu et al., 2004; Lu et al., 2007). The optimization and validation of primers and probes were performed using standard ABI protocols. PCRs were performed in triplicate as described by Lu et al. (Lu et al., 2013).

$1 \mu \mathrm{g}$ total RNA of fish CNSS tissues from the salinity transfer experiments were treated with DNase (Invitrogen, UK), and then first strand cDNA was synthesised (SuperScript ${ }^{\mathrm{TM}} \mathrm{II}$ cDNA kit, Invitrogen, UK) according to the manufacturer's instructions using random primers. The real-time PCR was performed in a final volume of $25 \mu 1$ consisting of optimal concentration (12.5 ng) of reverse transcribed cDNA mixed with optimal concentrations of primers (300 $\mathrm{nM}$ for UI and beta-actin; $600 \mathrm{nM}$ for ion channels) and Taqman ${ }^{\mathrm{TM}}$ probe (100 $\mathrm{nM}$ for UI and beta-actin; $200 \mathrm{nM}$ for ion channels) and $\mathrm{qPCR}^{\mathrm{TM}}$ Master mix plus kit (Eurogentec, Belgium), using a standard amplification profile $\left(2 \mathrm{~min}\right.$ at $50^{\circ} \mathrm{C}, 10 \mathrm{~min}$ at $95^{\circ} \mathrm{C}$ and then 40 cycles of the following: $15 \mathrm{~s}$ at $95^{\circ} \mathrm{C}$ and $1 \mathrm{~min}$ at $60^{\circ} \mathrm{C}$ ).

Flounder $\beta$-actin was used as reference genes. Relative quantization values were expressed using the $2^{-\Delta \Delta \mathrm{Ct}}$ method as fold changes in the target gene normalized to the reference gene and related to the expression of a control sample (Lu et al., 2004; Lu et al., 2006).

\subsection{Statistical analysis}

Results from measurements of plasma osmolality, electrolytes, urophysial UI content and relative mRNA levels of UI, L-type $\mathrm{Ca}^{2+}$ channel, Ca-activated $\mathrm{K}^{+}$channel are expressed as 
means \pm SE. Differences between groups were analyzed by Student's $t$ test. Significance level were set at $p<0.05$.

\section{Results}

\subsection{Tissue distribution of flounder UI mRNA}

The relative mRNA expression levels in different tissues for UI were determined by real-time PCR (Fig.1). The results indicated that UI mRNA was predominantly expressed in CNSS, the relative UI mRNA levels in CNSS was 2226 times higher than the second most expressed tissue - fore brain. The UI mRNA level in fore brain, mid brain, olfactory bulb, hind brain, and bladder appeared greater than other non-CNSS tissues, whereas the fore brain appeared to express more UI than other regions of the brain.

\subsection{Plasma composition of flounder}

Osmolality, sodium, and chloride of plasma were significantly higher in SW- than FW-adapted fish in both of experimental series (Fig. 2). At $8 \mathrm{~h}$ and $24 \mathrm{~h}$ after transfer fish from SW to FW, plasma osmolality, sodium, and chloride were significantly lower compared with time-matched SW-maintained controls (Fig.2 A). Transfer fish from FW to SW caused increase in plasma osmolality, sodium, and chloride at $8 \mathrm{~h}$ and $24 \mathrm{~h}$ (Fig.2 B).

\subsection{UI mRNA levels and urophysis UI content}

No differences in relative CNSS UI mRNA expression levels were evident in SW- and FW- adapted flounder in both of experimental series (Fig.3 A and D). There were no statistically significant changes in urophysial stored UI, while UI content was higher in FW than SW fish in July but higher in SW than in FW-adapted fish in September (Fig.3 E and G). 
At $8 \mathrm{~h}$ after transfer fish from SW to FW, UI mRNA expression were significantly higher compared with time-matched SW maintained controls, while at 24 h no significant changes were observed in July (Fig.3 B; July). Urophysial stored UI showed a decrease trend in FW transferred fish relative to time-matched SW controls (Fig.3 C; July). At $8 \mathrm{~h}$ and $24 \mathrm{~h}$ after the reverse transfer from FW to SW, UI mRNA and urophysis UI was no apparent changes (Fig. $3 \mathrm{E}$ and F; September).

\subsection{L-type $\mathrm{Ca}^{2+}$ channels and $\mathrm{Ca}$-activated $\mathrm{K}^{+}$channels mRNA levels}

Expression of mRNA for L-type $\mathrm{Ca}^{2+}$ channels was significantly higher in SW- than in FW-adapted fish (Fig.4 A and C). Similarly a higher mRNA expression level for Ca-activated $\mathrm{K}^{+}$channels was seen in $\mathrm{SW}$-compared to $\mathrm{FW}$-adapted fish, but there was no significant change in July (Fig.5 A and C). Transfer fish from SW to FW or reverse transfer had no impact on expression level of L-type $\mathrm{Ca}^{2+}$ and Ca-activated $\mathrm{K}^{+}$mRNA expression (Fig $4 \mathrm{~B}$ and D; Fig 5 B and D).

\section{Discussion}

\subsection{Tissue distribution of UI mRNA}

The real-time expression data in this study confirmed the CNSS as the primary site of UI gene expression. This corroborate the results of our previous results in flounder and Beriner $e t$ al in the rainbow trout (Bernier et al., 2008; Craig et al., 2005; Lu et al., 2004). In the brain, the detection of UI transcripts in the telecephalon-preoptic region, optic tectum-thalmus, posterior brain and hypothalamaic region in flounder is consistent with results from goldfish (Bernier and Craig, 2005). In rainbow trout (Oncorhynchus mykiss) and carp (Cyprinus 
carpio), the majority of UI mRNA expression is also found in the CNSS relative to the brain (Barsyte et al., 1999; Ishida et al., 1986) . These suggest that this hormone plays its greatest role in peripheral endocrine actions from CNSS and has a comparatively small role from the brain. The highest expression of UI in non-neural tissue is in the urinary bladder of flounder. The regulation of osmotic pressure is related to the urinary system. Bladder is the final place to reabsorption water from urine. Previous studies show that urotensin I and II, will stimulate electrogenic $\mathrm{Na}^{+}$reabsorption across the urinary bladders (Loretz and Bern, 1981). The highest expression of UI in non-neural tissue is in the urinary bladder indicted that UI may also directly produce in the bladder associated with osmoregulation locally.

\subsection{Effect of transfer between SW and FW on plasma osmolality, sodium and chloride}

Flounders are able to survive in both FW and SW but, in common with other euryhaline fish species, maintain a lower blood tonicity in FW. In both of the July and September experimental series, osmolality, sodium, and chloride of plasma were significantly higher in SW- than FW- adapted flounder. The same effect of seawater to freshwater transfer on plasma osmolality and inorganic ion concentrations has previously been studied in the same species (Bond et al., 2002). It is notably that plasma osmolality in SW is higher than that in SW-SW in July experimental series, that is not mirrored in the plasma $\left[\mathrm{Na}^{+}\right]$or $\left[\mathrm{Cl}^{-}\right]$. On the contrary in September, plasma osmolality in FW is lower than that in FW-FW. Such effect may be due to combination of transfer handling stress and salinity changes, transit elevated cortisol or other stress hormone could alter plasma osmolality and plasma ions after transfer( $\mathrm{Lu}$ et al., 2013; Miguel Mancera et al., 2002), stress caused by transfer can cause changes in plasma osmolality but does not necessarily cause changes in plasma $\left[\mathrm{Na}^{+}\right]$or $\left[\mathrm{Cl}^{-}\right]$, which may cause 
changes in other component in plasma. Such stress and elevated cortisol level will return to normal levels after two days (Bolasina, 2011; Hiroi et al., 1997)

\subsection{Effect of transfer between SW and FW on UI mRNA levels and urophysis UI content}

European flounder shows adaptation to both marine and freshwater environments, associated with its annual migratory/reproductive cycle (Marley et al., 2007). Our previous studies have confirmed UI expression peaked in late summer (August), possibly in anticipation of the physiological challenges associated with offshore migration (Lu et al., 2007). In this study, expression of UI in CNSS was no apparently difference between SWand FW- adapted fish in July and September. Similarly, there appeared to be no consistent difference in the CNSS between chronically SW- and FW-adapted fish in terms of UII mRNA expression ( $\mathrm{Lu}$ et al., 2006). It is notably that in July, while no statistically differences, urophysis UI content in FW-adapted fish is higher than that in SW-adapted.

UI is known to be associated with osmoregulatory role and cardiovascular functions in fish (McCrohan et al., 2007; Winter et al., 2000). Previous studies have also reported changes in the immunoreactive pattern of UI and the ultrastructural appearance of the CNSS in response to salinity alternations (Arnold-Reed et al., 1991; Larson and Madani, 1991; Larson and Madani, 1996). Similarly, UI mRNA level in CNSS is shown to be upregulated in rainbow trout when they were transferred from FW to SW (Craig et al., 2005). Together above studies, transfer to a hyperosmotic environment results in an increase in Dahlgren cell UI immunoreactivity and mRNA expression, a decrease in urophysis UI signal, and a reduction in the abundance of urophysis neurosecretory granules. In this study, we observed that UI mRNA expression was significantly upregulated in fish transfer from SW to FW at $8 \mathrm{~h}$, but no 
differences were seen at $24 \mathrm{~h}$. In parallel, urophysis UI content was appeared no changes at 8 $\mathrm{h}$, but decreased at $24 \mathrm{~h}$ in transfer from SW to FW compared with SW time-matched control. In contrast, rainbow trout exposured to SW conditions elicited marked increases in the levels of UI transcripts in the CNSS at 24, 72, and $168 \mathrm{~h}$ post transfer (Craig et al., 2005). Compared with rainbow trout, flounder has lower metabolic rate and may response less to the environmental changes (Craig et al., 2005; Lu et al., 2006; Rupia et al., 2016; Stiller et al., 2017). Further more, previous studies have indicated daily changes in peptide mRNA expression levels may only change the level of cell expression to compensate for loss of stored peptides during higher secretion periods (Lu et al., 2013). Our finding together with the previous results, suggest that the modulation secretion of UI from CNSS may be more important than modification of peptide mRNA expression levels in flounder when response to moderate environmental challenges.

\subsection{Effect of transfer between SW and FW on L-type $\mathrm{Ca}^{2+}$ channels and Ca-activated $\mathrm{K}^{+}$ channels mRNA level}

In mammalian neuroendocrine cells, high frequency, patterned bursts of action potentials have been shown to enhance efficiency of peptide secretion from terminals, when compared to tonic, unpatterned, activity (Bicknell et al., 1988; Cazalis et al., 1985), indicating that bursting provides an important control on secretory output. In founder Dahlgren cells, the L-type $\mathrm{Ca}^{2+}$ channels (after-depolarising potential, ADP) and Ca-activated $\mathrm{K}^{+}$channels (depolarising after potentials, DAP) have been shown to underlie patterned bursting activity, which is thought to promote more efficient peptide release (Brierley et al., 2004). In our study, expression level of L-type $\mathrm{Ca}^{2+}$ channel is lower in FW-adapted flounder CNSS than in 
SW-adapted flounder CNSS in both season. In consistent with our results, electrophysiological experiments have shown that bursting activity in Dahlgren cells is less robust in FW-adapted compared to SW-adapted fish (Ashworth et al., 2005; Brierley et al., 2003) and this is due, at least in part, to a reduction in $\mathrm{Ca}^{2+}$ channel-dependent ADP and Ca-activated $\mathrm{K}^{+}$channels-dependent DAP (Brierley et al., 2003). In this study, we also examined L-type $\mathrm{Ca}^{2+}$ channels or Ca-activated $\mathrm{K}^{+}$channels gene expression in fish transferred from SW to FW and reverse transfer. The results showed that there was no appeared difference in the CNSS neuroendocrine system between SW- and FW- transfer fish in terms of $\mathrm{L}$-type $\mathrm{Ca}^{2+}$ channels or Ca-activated $\mathrm{K}^{+}$channels mRNA levels.

Our findings, together with the previous results, suggest that the UI in the CNSS of euryhaline flounder play an important role in response to osmotic stress by Dahlgren cells activation and secretion. Further, elevated cortisol level induced by urotensins is also suggested to be involved in maintaining body homeostasis during stress due to its gluconeogenic action (Winter et al., 2000). We have shown that UI may modulate cortisol secretion, and suggest that the CNSS affords stress-specific stimulation of cortisol secretion (Kelsall and Balment, 1998) independent of the hypothalamic pituitary input (Winter et al., 2000).

In conclusion, this study provides additional evidence that the CNSS is the major tissue contributing to circulating UI. We were able to confirm that UI mRNAs are widely distributed, and that UI is likely involved in tissue-specific autocrine and paracrine roles in addition to their endocrine effects. The experimental results suggest that the UI in the CNSS of euryhaline flounder involved in response to osmotic stress by Dahlgren cells activation. 
Together these findings imply a neuroendocrine role for CNSS-produced UI acts as a modulator response to osmotic stress and plays important roles in the body fluid homeostasis.

\section{Authors' contributions}

Weiqun Lu designed and carried out experiments, interpreted the results,drafting and finalizing of the manuscript. Gege Zhu and Aqin Chen was responsible for experiments and data analysis. Catherine R. McCrohan and Richard Balment provided scientific concepts and direction, and finalized the manuscript. All authors read and approved the final manuscript.

\section{Acknowledgments}

This work was supported by the Biotechnology and Biological Sciences Research Council, National Natural Science Foundation of China (31572599, 41376134). 


\section{Reference}

Arnold-Reed, D.E., Balment, R.J., Mccrohan, C.R., Hackney, C.M., 1991. The caudal neurosecretory system of Platichthys flesus : General morphology and responses to altered salinity. Comparative Biochemistry \& Physiology Part A Physiology 99, 137-143.

Ashworth, A.J., Banks, J.R., Brierley, M.J., Balment, R.J., McCrohan, C.R., 2005. Electrical activity of caudal neurosecretory neurons in seawater and freshwater-adapted Platichthys flesus, in vivo. J. Exp. Biol. 208, 267-275.

Barsyte, D., Tipping, D.R., Smart, D., Conlon, J.M., Baker, B.I., Lovejoy, D.A., 1999. Rainbow trout (Oncorhynchus mykiss) urotensin-I: structural differences between urotensins-I and urocortins. Gen. Comp. Endocrinol. 115, 169-177.

Bernier, N.J., Alderman, S.L., Bristow, E.N., 2008. Heads or tails? Stressor-specific expression of corticotropin-releasing factor and urotensin I in the preoptic area and caudal neurosecretory system of rainbow trout. J. Endocrinol. 196, 637-648.

Bernier, N.J., Craig, P.M., 2005. CRF-related peptides contribute to stress response and regulation of appetite in hypoxic rainbow trout. Am. J. Physiol. Regul. Integr. Comp. Physiol. 289, R982-990.

Bernier, N.J., Lin, X., Peter, R.E., 1999. Differential expression of corticotropin-releasing factor (CRF) and urotensin I precursor genes, and evidence of CRF gene expression regulated by cortisol in goldfish brain. Gen. Comp. Endocrinol. 116, 461-477.

Bicknell, R.J., Leng, G., Lincoln, D.W., Russell, J.A., 1988. Naloxone excites oxytocin neurones in the supraoptic nucleus of lactating rats after chronic morphine treatment. J Physiol 396, 297-317.

Bolasina, S.N., 2011. Stress response of juvenile flounder (Paralichthys orbignyanus, Valenciennes 1839), to acute and chronic stressors. Aquaculture 313, 140-143.

Bond, H., Winter, M.J., Warne, J.M., McCrohan, C.R., Balment, R.J., 2002. Plasma concentrations of arginine vasotocin and urotensin II are reduced following transfer of the euryhaline flounder (Platichthys flesus) from seawater to fresh water. Gen. Comp. Endocrinol. 125, 113-120.

Brierley, M.J., Ashworth, A.J., Banks, J.R., Balment, R.J., McCrohan, C.R., 2001. Bursting properties of caudal neurosecretory cells in the flounder Platichthys flesus, in vitro. J. Exp. Biol. 204, 2733-2739.

Brierley, M.J., Ashworth, A.J., Craven, T.P., Woodburn, M., Banks, J.R., Lu, W., Riccardi, D., Balment, R.J., McCrohan, C.R., 2003. Electrical activity of caudal neurosecretory neurons in seawater- and freshwater-adapted flounder: responses to cholinergic agonists. J. Exp. Biol. 206, 4011-4020.

Brierley, M.J., Bauer, C.S., Lu, W., Riccardi, D., Balment, R.J., McCrohan, C.R., 2004. Voltage- and $\mathrm{Ca} 2+-d e p e n d e n t$ burst generation in neuroendocrine Dahlgren cells in the teleost Platichthys flesus. J. Neuroendocrinol. 16, 832-841.

Cazalis, M., Dayanithi, G., Nordmann, J.J., 1985. The role of patterned burst and interburst interval on the excitation-coupling mechanism in the isolated rat neural lobe. J Physiol 369, 45-60.

Conlon, J.M., Yano, K., Waugh, D., Hazon, N., 1996. Distribution and molecular forms of urotensin II and its role in cardiovascular regulation in vertebrates. The Journal of experimental zoology 275, 226-238.

Craig, P.M., Al-Timimi, H., Bernier, N.J., 2005. Differential increase in forebrain and caudal neurosecretory system corticotropin-releasing factor and urotensin I gene expression associated with seawater transfer in rainbow trout. Endocrinology 146, 3851-3860.

Flik, G., Klaren, P.H., Van den Burg, E.H., Metz, J.R., Huising, M.O., 2006. CRF and stress in fish. Gen. Comp. Endocrinol. 146, 36-44.

Greenwood, M.P., Flik, G., Wagner, G.F., Balment, R.J., 2009. The corpuscles of Stannius, calcium-sensing 
receptor, and stanniocalcin: responses to calcimimetics and physiological challenges. Endocrinology 150, 3002-3010.

Hiroi, J., Sakakura, Y., Tagawa, M., Seikai, T., Tanaka, M., 1997. Developmental changes in low-salinity tolerance and responses of prolactin, cortisol and thyroid hormones to low-salinity environment in larvae and juveniles of Japanese flounder, Paralichthys olivaceus. Zool. Sci. 14, 987-992.

Ishida, I., Ichikawa, T., Deguchi, T., 1986. Cloning and sequence analysis of cDNA encoding urotensin I precursor. Proc Natl Acad Sci U S A 83, 308-312.

Kelsall, C.J., Balment, R.J., 1998. Native urotensins influence cortisol secretion and plasma cortisol concentration in the euryhaline flounder, platichthys flesus. Gen. Comp. Endocrinol. 112, 210-219.

Larson, B.A., Madani, Z., 1991. Increased urotensin I and II immunoreactivity in the urophysis of Gillichthys mirabilis transferred to low salinity water. Gen. Comp. Endocrinol 83, 379-387.

Larson, B.A., Madani, Z., 1996. Sequential changes in urotensin immunoreactivity patterns in the trout, Oncorhynchus mykiss, caudal neurosecretory system in response to seawater challenge. Zool. Sci. 13, 403-414.

Lederis, K., Letter, A., McMaster, D., Moore, G., Schlesinger, D., 1982. Complete amino acid sequence of urotensin I, a hypotensive and corticotropin-releasing neuropeptide from Catostomus. Science 218, 162-165.

Loretz, C.A., Bern, H.A., 1981. Stimulation of sodium transport across the teleost urinary bladder by urotensin II. Gen. Comp. Endocrinol. 43, 325-330.

Lu, W., Dow, L., Gumusgoz, S., Brierley, M.J., Warne, J.M., Mccrohan, C.R., Balment, R.J., Riccardi, D., 2004. Coexpression of corticotropin-releasing hormone and urotensin i precursor genes in the caudal neurosecretory system of the euryhaline flounder (Platichthys flesus): a possible shared role in peripheral regulation. Endocrinology 145, 5786.

Lu, W., Greenwood, M., Dow, L., Yuill, J., Worthington, J., Brierley, M.J., McCrohan, C.R., Riccardi, D., Balment, R.J., 2006. Molecular characterization and expression of urotensin II and its receptor in the flounder (Platichthys flesus): a hormone system supporting body fluid homeostasis in euryhaline fish. Endocrinology 147, 3692-3708.

Lu, W., Jin, Y., Xu, J., Greenwood, M.P., Balment, R.J., 2017. Molecular characterisation and expression of parathyroid hormone-related protein in the caudal neurosecretory system of the euryhaline flounder, Platichthys flesus. Gen. Comp. Endocrinol. 249, 24-31.

Lu, W., Worthington, J., Riccardi, D., Balment, R.J., McCrohan, C.R., 2007. Seasonal changes in peptide, receptor and ion channel mRNA expression in the caudal neurosecretory system of the European flounder (Platichthys flesus). Gen. Comp. Endocrinol. 153, 262-272.

Lu, W., Zhang, Y., Xiong, J., Balment, R., 2013. Daily rhythms of urotensin I and II gene expression and hormone secretion in the caudal neurosecretory system of the euryhaline flounder (Platichthys flesus). Gen. Comp. Endocrinol. 188, 189-195.

Marley, R., Lu, W., Balment, R.J., Mccrohan, C.R., 2007. Evidence for nitric oxide role in the caudal neurosecretory system of the European flounder, Platichthys flesus. Gen. Comp. Endocrinol 153, 251.

McCrohan, C.R., Lu, W., Brierley, M.J., Dow, L., Balment, R.J., 2007. Fish caudal neurosecretory system: a model for the study of neuroendocrine secretion. Gen. Comp. Endocrinol. 153, 243-250.

Miguel Mancera, J., Laiz Carrion, R., del Pilar Martin del Rio, M., 2002. Osmoregulatory action of PRL, GH, and cortisol in the gilthead seabream (Sparus aurata L). Gen. Comp. Endocrinol. 129, 95-103.

Rupia, E.J., Binning, S.A., Roche, D.G., Lu, W.Q., 2016. Fight-flight or freeze-hide? Personality and metabolic phenotype mediate physiological defence responses in flatfish. J. Anim. Ecol. 85, 927-937.

Stiller, K.T., Vanselow, K.H., Moran, D., Riesen, G., Koppe, W., Dietz, C., Schulz, C., 2017. The effect of diet, temperature and intermittent low oxygen on the metabolism of rainbow trout. Br J Nutr 117, 784-795. 
Winter, M.J., Ashworth, A., Bond, H., Brierley, M.J., McCrohan, C.R., Balment, R.J., 2000. The caudal neurosecretory system: control and function of a novel neuroendocrine system in fish. Biochem. Cell Biol. 78, 193-203.

Yasuda, T., Masaki, T., Gotoh, K., Chiba, S., Kakuma, T., Yoshimatsu, H., 2012. Intracerebroventricular administration of urotensin II regulates food intake and sympathetic nerve activity in brown adipose tissue. Peptides 35, 131-135. 


\section{Figure Captions}

Fig. 1. Distribution of UI mRNA in different tissues of European flounder. The gene expression of each tissue relative to head kidney analyzed by real-time RT-PCR with $\beta$-actin as reference gene. Values are estimates for pooled samples from 20 fishes. The relative mRNA expression level of UI (CNSS > fore brain $>$ mid brain $>$ alfactory bulb $>$ hind brain $>$ bladder $>$ optical nerve $>$ hypothalamus $>$ egg).

Fig.2. Effect of transfer between SW and FW on plasma osmolality, sodium, and chloride (A, July; B, September). Values plotted are means $\pm \mathrm{SE}, \mathrm{n}=7-8$ per group, ${ }^{*} p<0.05$, ${ }^{* *} p<0.005$, ${ }^{* * *} p<0.0005$. An independent-samples $t$ test was used to assess differences between chronically adapted FW and SW flounder and between experimental and time-matched controls at each time point.

Fig.3. UI mRNA levels and urophysis UI content in CNSS from flounder chronically adapted to SW or FW (A and C, July; E and G, September), and at $8 \mathrm{~h}$ and $24 \mathrm{~h}$ following experimental transfer from SW to FW (B and D, control SW to FW, July), and from FW to SW (F and H, control FW to FW, September). Values plotted are means+ SE, $\mathrm{n}=7-8$ per group, ${ }^{*} * P<0.005$, compared to time-matched control.

Fig.4. L-type $\mathrm{Ca}^{2+}$ channels mRNA levels in CNSS from flounder chronically adapted to SW or FW (A, July; C, September), and at $8 \mathrm{~h}$ and $24 \mathrm{~h}$ following experimental transfer from SW to FW (B, control SW to $\mathrm{FW}$ ), and from FW to SW (D, control FW to FW, September). Values plotted are means $\pm \mathrm{SE}, \mathrm{n}=7-8$ per group, ${ }^{*} p<0.05$, compared to time-matched control.

Fig.5. Effect of salinity changes on mRNA expression for Ca-activated $\mathrm{K}^{+}$channels in CNSS from flounder chronically adapted to SW or FW (A, July; C, September), and at $8 \mathrm{~h}$ and $24 \mathrm{~h}$ following experimental transfer from SW to FW (B, control SW to FW), and from FW to SW (D, control FW to FW, September). Values plotted are means $\pm \mathrm{SE}, \mathrm{n}=7-8$ per group, ${ }^{*} p<0.05$, compared to time-matched control.

\section{Figure 1.}




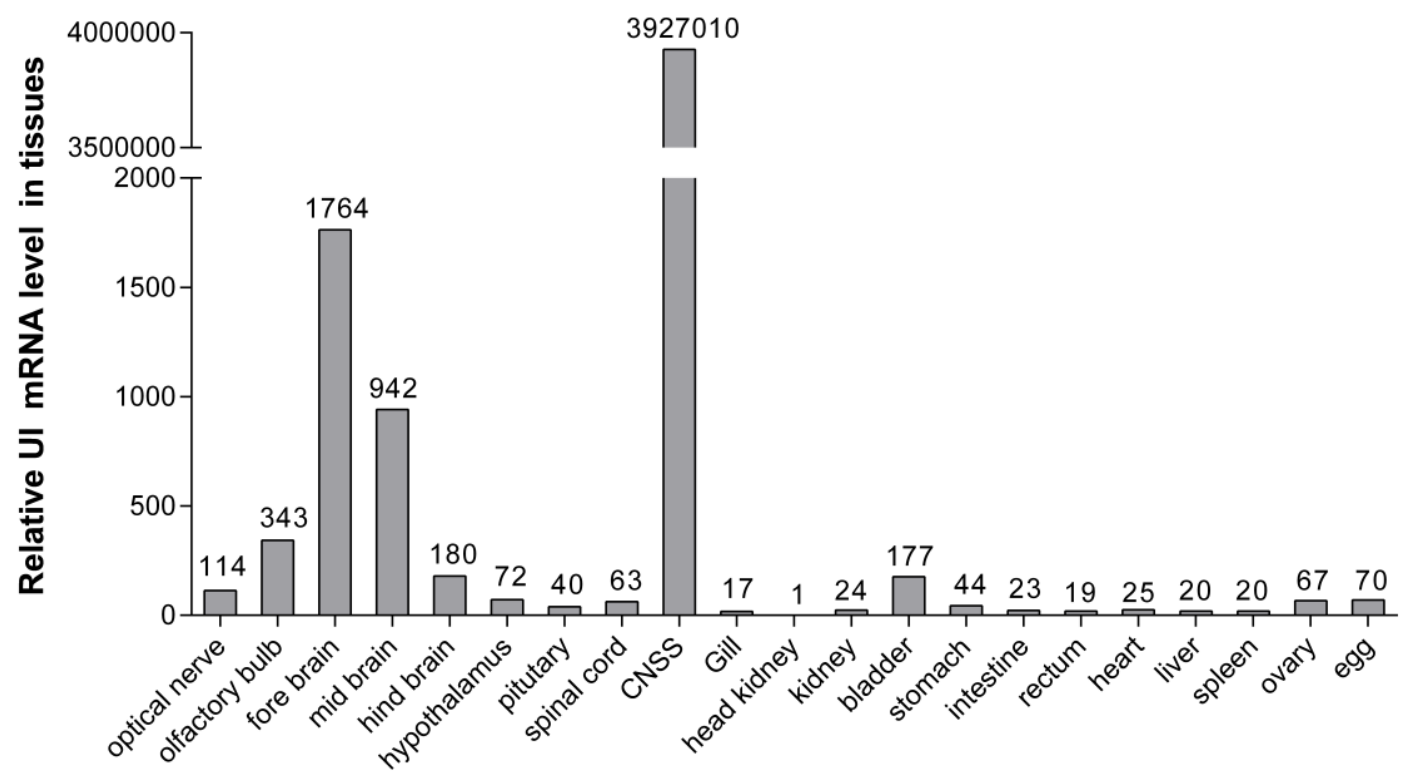

Figure 2.
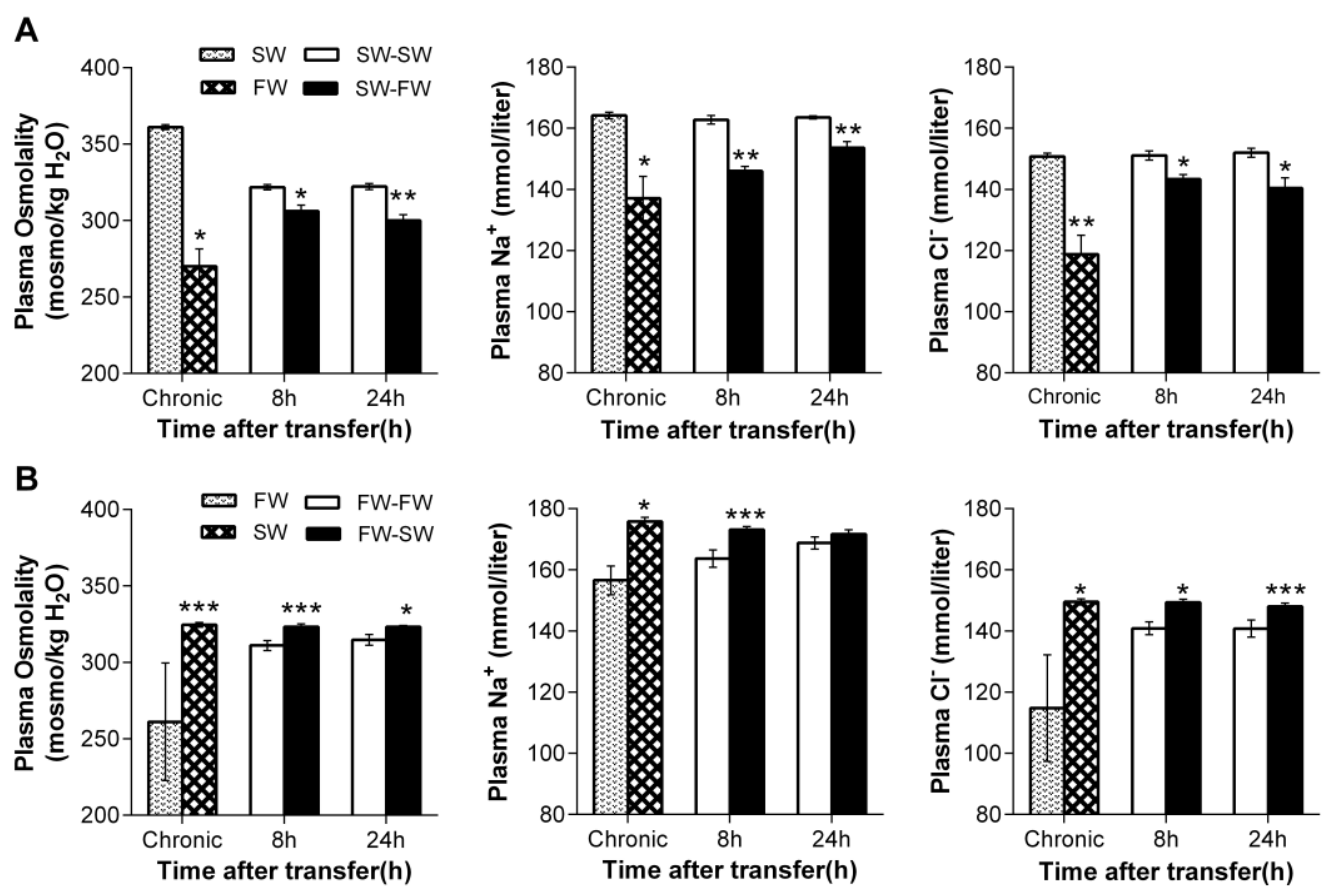

Figure 3. 

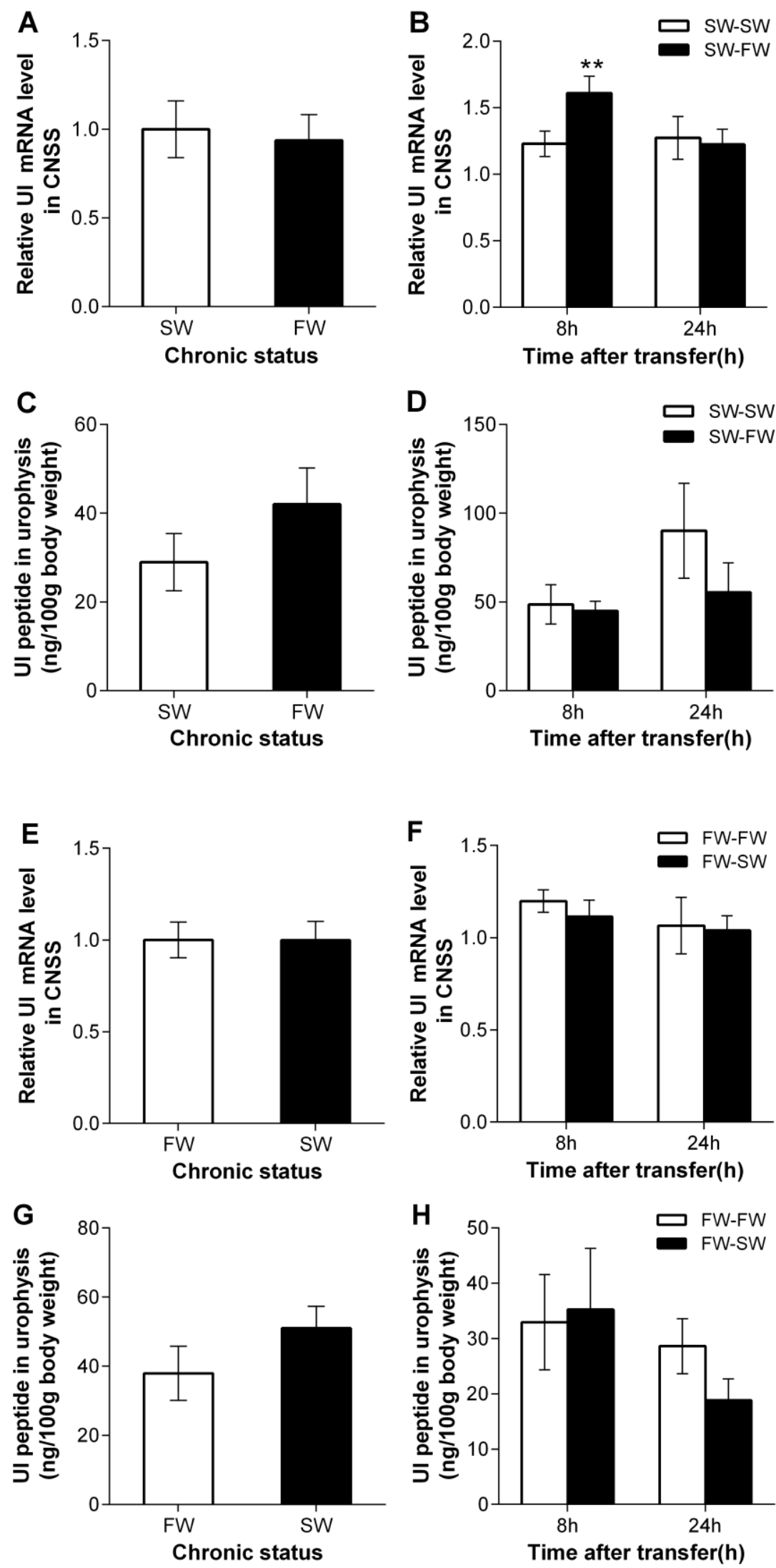

Figure 4. 
A

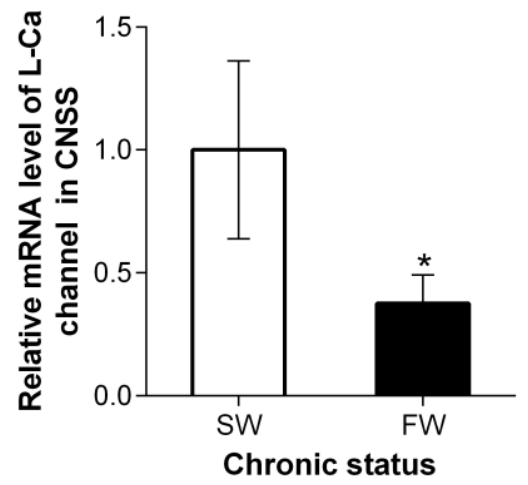

C

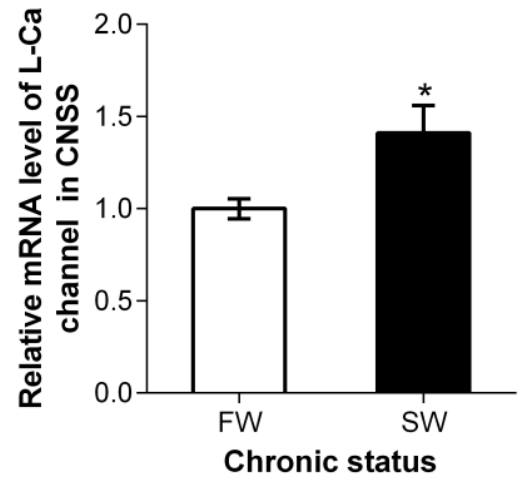

B

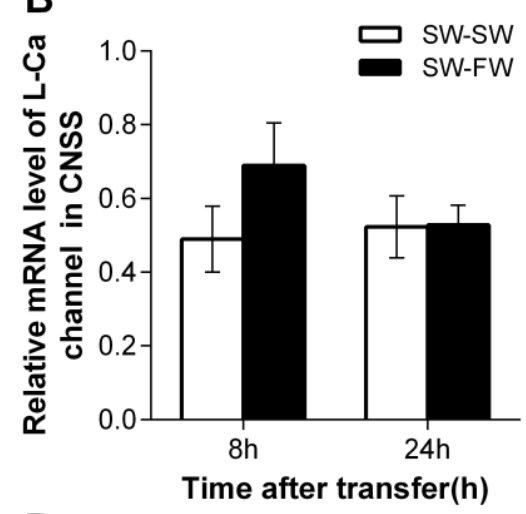

D

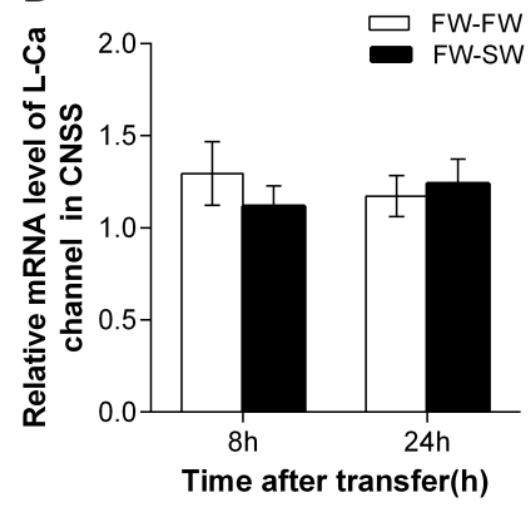

Figure 5. 
A
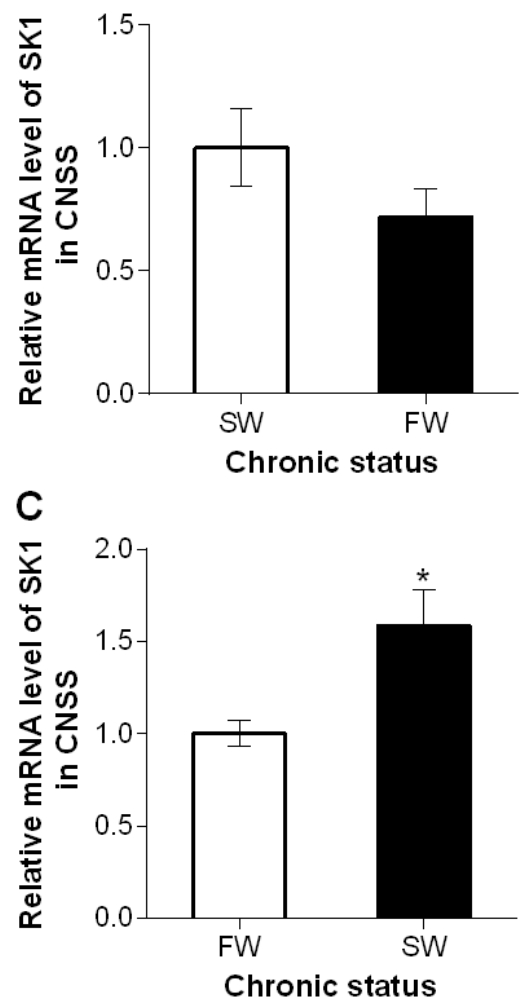

B
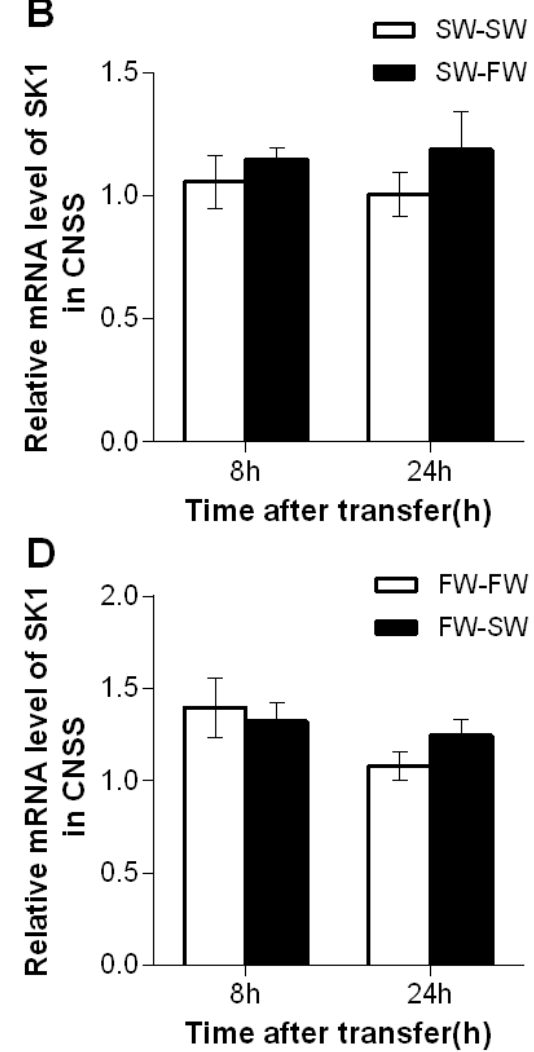


\section{Highlights:}

1. The effect of seawater to freshwater transfer (and vice versa) on UI and ion channel expression in the CNSS was examined.

2. An involvement of UI in adapt transfer from seawater to freshwater in flounder.

3. Ion channel mRNA expression was lower in CNSS from freshwater-adapted flounder as opposed to seawater. 


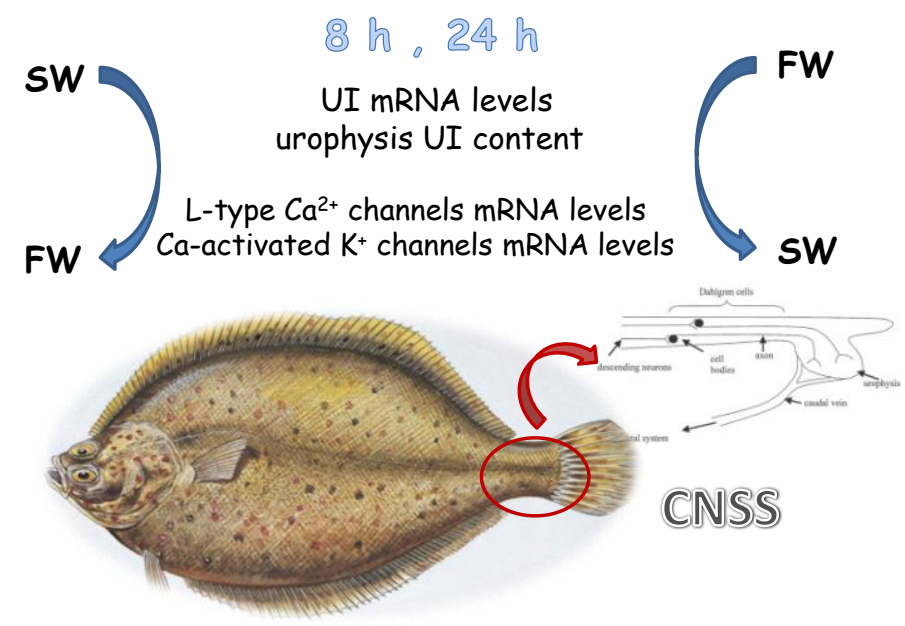

CNSS UI act as a modulator response to osmotic stress. 